\title{
Positive obligations and the European Court of Human Rights
}

\author{
Professor BRICE DiCKSON*
}

School of Law, Queen's University Belfast

\begin{abstract}
A nalysts of the ever-burgeoning jurisprudence of the European Court of Human Rights

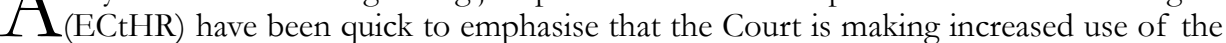
concept of "positive obligations". ${ }^{1}$ In other words, rather than merely requiring Council of Europe states to refrain from interfering with individuals' rights, the Court is frequently insisting that those states take direct action to protect those rights. States are no longer just being told to allow individuals to live their lives as they please provided they cause no harm to others; they are being required to do things for those individuals that give them a certain quality of life.
\end{abstract}

There is, however, some potential for a lack of clarity in this context. In reality, while the distinction between negative obligations and positive obligations may seem attractive, the dichotomy is a false one, as any cursory reading of the classic writings of Wesley Hohfeld will indicate. ${ }^{2}$ All rights ("claim rights" in Hohfeld's terminology) have correlative obligations (or "duties") and nothing is added to the truth of this statement by sub-dividing obligations into those that are negative and those that are positive. Negative obligations can easily be restated as positive obligations (and vice versa), and all rights can just as readily be described as having correlative obligations that are both positive and negative. Thus, a right to liberty means not just that the state must not arbitrarily deprive an individual of his or her liberty, but also that it must take steps to ensure that no one else brings about such a deprivation of liberty. Likewise, a right to a fair trial means that the state must not stack the odds against a claimant or defendant during a trial but, in addition, it must also ensure that others do not create such an imbalance either. What use is the right to free speech, for example, if every time someone says something that is controversial someone else can lawfully come along and harm that person for expressing such a view? Put more simply, a duty to not do something can always (or virtually always) be re-phrased as a duty to do something.

To some extent the simplicity of this point is conveyed quite admirably by the first Article of the European Convention on Human Rights and Fundamental Freedoms

* Professor of International and Comparative Law, Director of the Human Rights Centre, School of Law, Queen's University Belfast.

1 The locus classicus is already A Mowbray, The Development of Positive Obligations under the European Convention on Human Rights by the European Court of Human Rights (Oxford: Hart Publishing 2004), helpfully reviewed by Ed Bates at (2005) 5 Human Rights LR 191.

2 See his "Some fundamental legal conceptions as applied in judicial reasoning" (1913) 23 Yale LJ 16, and the follow-up article in (1917) 27 Yale LJ 710. 
(ECHR), which reads, under the heading "Obligation to respect human rights", 3 as follows: "The High Contracting Parties shall secure to everyone within their jurisdiction the rights and freedoms defined in Section I of this Convention." In addition, Article 17 of the Convention, under the heading "Prohibition of abuse of rights", makes it clear that:

Nothing in this Convention may be interpreted as implying for any State . . any right to engage in any activity or perform any act aimed at the destruction of any of the rights and freedoms set forth herein or at their limitation to a greater extent than is provided for in the Convention.

The Convention itself, therefore, presupposes that Council of Europe states will actually do things to "secure" Convention rights and to save them from "destruction".

It is submitted that use of the term "positive obligations" has proliferated for three reasons. First, the supposed distinction between first-generation civil and political rights and second-generation economic and social rights has encouraged the adoption of contrasting terminology, partly because the wording of the International Covenant on Civil and Political Rights is largely based on the "Everyone has the right . ." model, while the wording of the International Covenant on Economic, Social and Cultural Rights prefers the model "The States Parties recognize that (or undertake that) ..." The difference in the models reflects the different approaches adopted by the Western and Eastern bloc countries at the time of the negotiations around the Covenants. As regards social and economic rights, Western countries were happy with a formulation that in their eyes played down the justiciability of the rights by individuals, while Eastern countries were content with wording that put the emphasis on what government should do for people, not on what individuals could claim from their governments. But today most human rights theorists, as well as activists, accept the hollowness of this apparent difference of approach and proudly affirm the indivisibility of human rights. ${ }^{4}$ To be consistent they should also assert the fallacy in trying to maintain a distinction between negative and positive obligations.

The second reason for the greater use of "positive obligations" is quite simply that the idea that human rights can be adequately protected if states content themselves with merely standing by and doing nothing has become patently absurd. Societies are too complex for a purely passive approach to human rights to be sufficient. This is all the more so in societies that wish to uphold the ideals of democracy and the rule of law. The Preamble to the ECHR acknowledges this when it reminds us that in signing the Convention governments are reaffirming their profound belief in the fundamental freedoms, which are the foundation of justice and peace and which are best maintained by an effective political democracy and by a common observance of the human rights upon which those freedoms depend. ${ }^{5}$ The Preamble also states that one method by which Council of Europe states can pursue greater unity is by maintaining and further realising human rights and fundamental freedoms. ${ }^{6}$ The Convention is thus part of a building project, not merely a fire-fighting operation. It presupposes the construction of a better rights framework, not just the prevention of the destruction of whatever framework already exists.

3 Headings were not introduced into the text of the ECHR until the amendments made by Article 2(1) of Protocol 11 in 1998.

4 See e.g. para. 5 of the Vienna Declaration resulting from the World Conference on Human Rights in 1993: "All human rights are universal, indivisible and interdependent and interrelated. The international community must treat human rights globally in a fair and equal manner, on the same footing, and with the same emphasis."

5 Para. 4. Para. 5 refers as well to European countries' "common heritage of political traditions, ideals, freedom and the rule of law".

6 Para. 3. 
The third stimulus for the concept of "positive obligations" is the perfectly understandable commitment by the European Court to treat the Convention as a living and evolving document, one that provides effective protection of human rights. The Court, especially since its transformation into a full-time body in 1998, wants to be seen not just as a factory churning out thousands of judgments each year, but as an institution that can make a real difference to the lives of people throughout the continent. In case after case it has asserted that the Convention must be interpreted in a way that guarantees rights that are "not theoretical or illusory but practical and effective". ${ }^{7}$ Hence, there would be little point in the Convention's conferring the right to life if the Court did not take this to mean that a state must act to stop people being killed as well not kill them itself. And, if a killing does occur, the right to life would be rendered almost completely useless if a state did not have to carry out an effective investigation into how it happened: such an investigation is not itself a remedy, and is not therefore a requirement flowing from Article 13's guarantee of an effective remedy for violations of the rights and freedoms set forth in the Convention. This practical approach to human rights is consistent with that argued for by Henry Shue, who in a seminal work emphasised the importance of "respecting" and "fulfilling" rights as well as "protecting" them. ${ }^{8}$ South Africa's 1996 Constitution adds a fourth important leg to the stool, that of "promoting" rights.?

A related point is that, through the procedural reforms now under way thanks to the coming into force of Protocol 14 on 1 June 2010 (the Court issued its first decision under the new admissibility criterion on 28 June), ${ }^{10}$ and as a result of the development of the very significant "pilot judgment" device, ${ }^{11}$ the European Court is in the process of becoming a truly "constitutional court" rather than one which aims to deal with every allegation of a human rights violation, great or small, in all 47 countries. ${ }^{12}$ In that capacity it wants to strive towards a holistic approach to rights protection, one that ignores irrelevant barriers and embeds basic values.

The main difficulty with courts telling states what they must do as opposed to what they must not do is, supposedly, that of democratic accountability. Judges are not elected and therefore cannot be held to account for their decisions in the same way as politicians. But when judges tell states what they must not do this can be just as big a constraint on the politicians' freedom of action as telling them what they must do. An analysis of the dialogue between the UK's House of Lords (latterly the Supreme Court) and the Labour governments of 2001-2010 illustrates this point very clearly. Government ministers were virtually tearing their hair out when the country's most senior judges ruled, first, that the

7 This approach seems to have been first articulated in Artico v Italy (1980) 3 EHRR 1.

8 H Shue, Basic Rights: Subsistence, affluence, and US foreign policy (New Jersey: Princeton University Press 1980).

9 S. $7(2)$.

10 This was in Adrian Mihai Ionescu v Romania App. No 36659/04, where the applicant claimed that a coach company had not fulfilled its promise to provide reclining seats on a trip he had booked between Bucharest and Madrid and that the Romanian courts had not dealt fully and publicly with his complaint. The ECtHR ruled that, in line with the new Article 35(3)(b) ECHR, the applicant had not suffered "a significant disadvantage" since his financial loss was estimated at 90 euros, respect for human rights as defined in the convention did not require an examination of the application on the merits since the relevant legal provisions in Romania had been repealed, and the case had been duly considered by a domestic court. See, too, Korolev (II) v Russia App. No 25551/05, 27 July 2010.

11 See the excellent study by P Leach, H Hardman, S Stephenson and B Blitz, Responding to Systemic Human Rights Violations - An analysis of pilot judgments of the European Court of Human Rights and their impact at national level (Mortsel, Belgium: Intersentia 2010). And see now Rumpf v Germany App. No 463044/06, judgment of 2 September 2010.

12 For a compelling case in favour of this trend see S Greer, The European Convention on Human Rights: Achievements, problems and prospects (Cambridge: CUP 2006). 
indefinite detention without trial of foreign nationals reasonably suspected of terrorism was unlawful; ${ }^{13}$ then that use could not be made in a UK court of information that may have been obtained as a result of torture practised anywhere in the world; ${ }^{4}$ then that requiring a suspected terrorist to remain inside a small flat with little or no access to the outside world for more than 16 hours a day was not permissible; 15 and, finally, that when seeking to justify a control order issued against a suspected terrorist the government could not keep secret from the controlee the reasons why he or she was suspected of involvement in terrorism. ${ }^{16}$ The cases on control orders indicate that if the government wishes to interfere with the right to liberty it must actively mitigate the effects of that interference by ensuring that the person in question has access to a range of contacts that make life tolerable.

There is no knowing what developments have still to occur in the European Court's employment of the concept of "positive obligations". If it were to follow the example set by the Supreme Court of India, in the way in which that court has constructed a huge panoply of positive duties on the basis of the meagre negative obligation relating to the right to life contained in Article 21 of the Indian Constitution, ${ }^{17}$ then the resulting case law could be very impressive indeed. ${ }^{18}$ It might in that way extend the application of the ECHR deep into the realm of economic and social rights. Already the Court's interpretation of Article 1 of Protocol 1 has come close to creating a right to an adequate standard of living. The Court has been less activist in sculpting a right to healthcare out of Articles 2 or 3, or a right to fair working conditions out of Article 4, or a right to shelter out of Article 8, but the potential for these developments to occur clearly exists.

In this 60th anniversary year of the start of the jurisprudence of the ECtHR, it is appropriate to take stock of where the Court has got to in its "positive" work to date. ${ }^{19}$ To that end a workshop was held in the Human Rights Centre of the School of Law at Queen's University Belfast on 24 March 2010. The five papers included in the Special Issue of this journal were all first aired at that workshop, but have been polished and updated since then. ${ }^{20}$

Catherine Donnelly's piece explores in a most instructive way the relationship between positive obligations and privatisation. She points out that it is conceivable that a national court, or the ECtHR, could devise constraints for states' privatisation policies: not just as to how the privatisation rolls out but also as to what functions can be privatised in the first place. It is hard to imagine the Court tolerating the privatisation of criminal prosecutions, but where should the line be drawn as regards the adjudication of non-criminal disputes? And will the Court ever insist that privatisation has to be conditional upon the state retaining some responsibilities under the ECHR? In so far as the state is already under a positive obligation to put in place an effective justice system, the buck must always surely stop with it if an individual is unable to obtain an effective and fair "trial" of his or her

13 A v Secretary of State for the Home Dept [2004] UKHL 56, [2005] 2 AC 68 (9 judges).

14 A v Secretary of State for the Home Dept (No 2) [2005] UKHL 71, [2006] 2 AC 221 (7 judges).

15 Secretary of State for the Home Dept v JJ [2007] UKHL 45, [2008] 1 AC 385.

16 Secretary of State for the Home Dept v AF [2008] UKHL 28, [2009] 3 WLR 74.

17 "No person shall be deprived of his life or personal liberty except according to procedure established by law."

18 See e.g. Arun Ray Mohapatra, Public Interest Litigation and Human Rights in India (Radha Publications: New Delhi 2003).

19 The ECtHR's first judgment was issued on 14 November 1960 (Lawless v Ireland (No 1)). The Court actually held its first session on 23 February 1959.

20 A sixth paper was delivered by Paul Mageean, of the University of Ulster on the way in which the European Court has conjured out of Article 2 of the ECHR a state obligation to conduct an effective investigation into suspicious deaths. For a related publication, see Gordon Anthony and Paul Mageean, "Habits of mind and 'truth-telling': Article 2 in post-conflict Northern Ireland” in J Morison, K McEvoy and G Anthony (eds), Judges, Transition and Human Rights (Oxford: OUP 2007). 
grievance. Donnelly also explains how, paradoxically, the remedies available to the "victim" of privatisation may be stronger when the obligation that has been violated is of the positive rather than the negative variety. It seems that some positive duties cannot be shaken off by the state merely through contracting out its functions to a private body: the very contracting out, if conducted in a way which does not pay sufficient attention to the rights of individuals affected by the decision as opposed to the interests of society as a whole, may trigger a violation of the Convention.

Ellie Palmer examines an area which is a common candidate for privatisation - the provision of housing - but concludes that, while the ECtHR has made some important strides down the positive obligation path, it has not yet reached the point where vulnerable homeless people are entitled to be provided with shelter. She explains how the Court is still rather obsessed with the negative approach to rights, citing decisions in several cases involving the United Kingdom. There are clear indications that the Court has been trying to develop both Article 6 and Article 14 - especially in relation to the right to enjoyment of possessions guaranteed by Article 1 of Protocol 1 - in a manner which comes close to imposing a positive duty to supply socio-economic goods, including housing, but the inference Palmer draws from this is that the very fact that such an indirect approach has had to be adopted belies a reluctance on the part of the ECtHR to step on the toes of national legislatures in this field. She rightly observes that the insistence on formal due process and non-discrimination is not enough to constitute a principled and systematic commitment to social justice. She reminds us of some candles in the wind within recent UK case law (in particular Bernard ${ }^{21}$ and Limbuela), ${ }^{22}$ but also has to acknowledge that the UK Supreme Court looks as if it wants to row back on the idea that a right not to be homeless can be a "civil right" (and ex hypothesi a Convention right). ${ }^{23}$

Ursula Kilkelly presents a fascinating account of how the ECtHR has exploited the concept of positive obligations in the specific context of children's rights. Indeed, it is the reliance on positive obligations that has made the ECHR really relevant to children. Kilkelly substantiates this by setting out how exactly the ECtHR has employed positive duties in order to develop children's rights to family ties, to a personal identity and to a safe environment. These duties have also been vital to the development of a right to a family life (for the benefit of adults as well as children), especially in cases where a child has been abducted. The author concludes by speculating on what lies ahead in this context: the possibilities are many, given the growing realisation that children are human beings in their own right who deserve positive assistance from the state to protect them from abusive parents and from other pernicious influences. We certainly have not heard the ECtHR's final words on questions such as an adopted child's right to know his or her parentage, a disabled child's right to an appropriate education, or a sick child's right to proper hospital treatment. The thorny issue of a state's duties vis-à-vis unborn children is also likely to be further explored before long.

Rory O'Connell's article examines the part that positive obligations have, and could, play in ensuring the protection of "political" rights. He focuses on the right to vote, the right to stand for election and the right to form and operate political parties, but he contextualises his discussion of those specific topics by considering the scope of the margin of appreciation in this field. Given that there are 47 member states of the Council of Europe, there is significant variety in the way in which elections and party politics are regulated.

21 Bernard v Enfield LBC [2002] EWHC (Admin) 2282.

22 R (Limbuela) v Secretary of State for the Home Dept [2005] UKHL 66, [2009] 1 AC 396.

23 Ali v Birmingham City Council [2010] UKHL 8, [2010] 2 WLR 471. 
Many of the practices in question have deep historical and cultural roots and it would be regarded as unacceptable in several government corridors for a group of judges in Strasbourg to dictate what is or is not appropriate within certain political cultures. Should non-nationals be allowed to stand for election, should all elected politicians have to swear allegiance to the state, should minority groups be guaranteed representation in the national parliament, should 17-year-olds be allowed to vote? The outstanding questions are legion. On top of this, one can think of numerous issues which, in a US context at least, would be exempt from judicial scrutiny because they are regarded as essentially "political questions": should a prime minister be able to sack a member of the government at will, should parliaments be allowed complete freedom to regulate their own activities regardless of the rights of individual politicians, and should big decisions - such as whether to go to war, whether to bail out depositors or creditors of a failing bank, or whether to devalue the national currency - ever be justiciable? Where, in other words, does the state's positive obligation to uphold democracy end and its right to sovereignty and autonomy begin?

The final contribution in this Special Issue, by David Russell, brings home the impact which positive obligations could and should have in the particular context of Northern Ireland. Working as he does for the Northern Ireland Human Rights Commission (but writing here in a purely personal capacity), Russell is in a good position to explain the thinking of the commission when it drafted its advice to the UK government on what should be contained in a Bill of Rights for Northern Ireland, although sadly it seems that those with real influence at Westminster (in any of the three major parties) are not persuaded of the need to have a Bill of Rights of the expansive nature that the commission wants. ${ }^{24}$ This does not mean, however, that more piecemeal reform is not possible or desirable and that the concept of positive obligations could not be invoked within specific legislative initiatives either in London or in Belfast. One of the last actions of the Labour government was to secure the enactment of the Equality Act 2010, section 1 of which requires public authorities, when making decisions of a strategic nature about how to exercise their functions, to "have due regard to the desirability of exercising them in a way that is designed to reduce the inequalities of outcome which result from socio-economic disadvantage". This is not yet part of Northern Ireland's law (and the commitment of the Northern Ireland Executive to a so-called Single Equality Bill has fallen away in recent years), but it is a good example of the "programmatic duty" which Russell highlights towards the end of his piece and there is no good reason for not replicating it in this jurisdiction.

It is strange that the apparent contrast between negative obligations and positive obligations plays such a prominent role in international human rights law, for it seems to play hardly any role at all at the national level. The reality, however, is that international courts are even more reluctant than national courts to issue judgments which give instructions to governments to do things. The rule of law does not yet operate at the international level in the way that it does within democratic states. That does not have to mean, however, that positive obligations can have no role at all to play. Incrementally, surreptitiously, they are slowly seeping into the ECtHR's case law. We can only hope that it will not be long before the trickle becomes a steady stream.

24 For the response of the Northern Ireland Office to the commission's advice, see its consultation paper, $A$ Bill of Rights for Northern Ireland: Next steps (November 2009). 